\title{
Inclusion and Marginalization of Learners in Secondary Education (Finland)
}

\section{Peltola, Marja}

Bloomsbury Publishing

2021

Peltola , M , Niemi , A-M \& Kosunen , S 2021, Inclusion and Marginalization of Learners in Secondary Education (Finland) . in J Kauko \& M T Tatto (eds), Bloomsbury Education and Childhood Studies: Articles. Bloomsbury Education and Childhood Studies, Bloomsbury Publishing , London . https://doi.org/10.5040/9781350996533.006

http://hdl.handle.net/10138/336860

https://doi.org/10.5040/9781350996533.006

unspecified

acceptedVersion

Downloaded from Helda, University of Helsinki institutional repository.

This is an electronic reprint of the original article.

This reprint may differ from the original in pagination and typographic detail.

Please cite the original version. 
Bloomsbury Education and Childhood Studies Article Template

\begin{tabular}{|l|l|}
\hline Article title & $\begin{array}{l}\text { Inclusion and Marginalisation of Learners in Secondary Education } \\
\text { (Finland) }\end{array}$ \\
\hline Author 1 & Marja Peltola \\
\hline $\begin{array}{l}\text { Author 1 } \\
\text { affiliation }\end{array}$ & Marja Peltola is post-doctoral researcher at University of Helsinki, Finland \\
\hline Author 2 & Anna-Maija Niemi, Sonja Kosunen \\
\hline $\begin{array}{l}\text { Author 2 } \\
\text { affiliation }\end{array}$ & $\begin{array}{l}\text { Anna-Maija Niemi is post-doctoral researcher at University of Helsinki, Finland. } \\
\text { Sonja Kosunen is assistant professor at University of Helsinki, Finland. }\end{array}$ \\
\hline Regional Editor & Jaakko Kauko \\
\hline Editor in Chief & Maria Teresa Tatto and lan Menter \\
\hline
\end{tabular}

\section{Keywords}

Ethnicity, disability, special needs, sexual and gender minorities, universalism

\section{Glossary terms}

Minoritization: Minoritization and minoritized position refer to the social processes of positioning parts of the population, based on their ethnicity, migration history or both, as ethnic minorities and therefore as implicitly inferior to the the ethnic majority - or the majoritized population. Unlike the seemingly objective term "ethnic minority", minoritization draws attention to power relations and relationality in defining positions of ethnic minorities and majorities.

LGBTIQ+: LGBTIQ+ is an acronym aiming for inclusiveness by encompassing the diversity of sexual and gender minorities. The letters refer to lesbian, gay, bisexual, trans, intersex and queer, and + acknowledges that the diversity of sexual minority identities extends even beyond these categories.

Three-tier support system: Reformed in 2011, educational support in the Finnish school system is organized in three categories: general, intensified and special support. All pupils are entitled to general support, which is part of everyday teaching and learning processes. If general support is not sufficient for fulfilling a pupil's needs, then pedagogical assessment is arranged and a plan for intensified support is drawn up, followed by a learning plan. If intensified support is not sufficient either, more extensive pedagogical assessments are made, leading to an official decision concerning special support.

\section{Research on inclusion and marginalization}

Research has shown that levels of inclusion in Finnish secondary education vary according to gender, social class, ethnicity, sexuality and other factors (e.g. Käyhkö 2006; Tolonen 2012; Aaltonen \& Karvonen 2016). The assumed category of an "ordinary" pupil excludes children and young people from racialized minorities, with LGBTIQ+ identities and with disabilities, which results in both structural inequalities and personal experiences of exclusion (e.g. Alanko 2014; Kurki 2019; Mietola \& Niemi 2014; Holmberg et al. 2018). Language and religion potentially produce further divisions in secondary education (From \& Sahlström 2017; Tainio et al. 2019; Zilliacus 2013, 2014; see also Huilla $\&$ Kosunen in this book). These differences have consequences in the transition from lowersecondary (13-16-year-olds, compulsory) to upper-secondary (16-19-year-olds) education, and may 
lead to further educational inequality and marginalisation (e.g. Kilpi-Jakonen 2011, 2017; Niemi 2015; Nylund et al. 2018).

In Finland, the concept of inclusion has been primarily attached to special needs education, meaning teaching pupils with special educational needs in general classrooms alongside other pupils and supporting them individually (Niemi \& Mietola 2017). It is only recently that the discussion has included issues related to ethnic minorities, racialization, sexual orientation and gender identity.

\section{Demographics}

Finland has 5.5 million inhabitants and two official languages, Finnish and Swedish (5.3\% of the population). The national Churches are the Lutheran (69.7\% of the population) and the Orthodox (about 1.1\%) (OSF 2019a). There is an indigenous Sami population and long-established minorities of Roma, Tatars, Jews and Russians. Among 13-18-year-olds, the percentage of pupils "with a foreign background" was 6.9 in 2017 (OSF 2019a, including so-called second generation but excluding those with a mixed heritage). The position of young people with a migrant background varies greatly according to their length of stay in Finland, their migratory background and their citizenship status, among other things. Unaccompanied refugee minors form a small but particularly vulnerable group.

According to a large national School Health Survey, about ten per cent of 15-16-year-olds identified themselves as other than heterosexual, and 5.6 per cent experienced their gender as non-binary (Luopa et al. 2017).

10.8 per cent of lower-secondary-level pupils received intensified support in 2018; 9.7 per cent received special support, of whom 32 per cent studied in special schools or educational groups. 20 per cent of students in upper-secondary vocational education received special support in 2017, of whom 86 per cent studied in mainstream groups whereas the rest were in special groups or special vocational-education institutes. (OSF 2019.) Thus, despite the principle of inclusion, a significant proportion of pupils with special educational needs still study in separate pedagogical environments. There is variation in how effectively schools are able to support their pupils. The current educational level of disabled youth is relatively high: almost all young people undertake some studies after basic education, but not all programs lead to a vocational qualification or to employment (Ahonen \& Lampinen 2017; Kauppila et al. 2018).

\section{Policies and laws}

The principle of universalism shapes the organization of secondary schools. Fundamental principles include allocation to a neighborhood school and the avoidance of "dead-ends" or the inability of young people to access higher education because of their earlier choices. Tracking starts late in Finland by international standards, after lower-secondary school at the age of 15 (approximately). Upper-secondary education is provided in separate general (chosen by $48 \%$ of the age-cohort in 2018 ) and vocational (52\%) schools. Even though the system allows progression from vocational to higher education, in 2017 only 10 per cent of university students had a vocational upper-secondary education, which includes those who had also pursued other studies (Vipunen 2019).

The core curriculum in both comprehensive and upper-secondary education reflects and is based on Equality and Anti-discrimination legislation, which acknowledges gender, ethnicity, disability, sexual orientation and gender identity as potential grounds for illegal discrimination. All state officials, including teachers and other school employees, are obliged to promote equality on these grounds. 
Up until 2018, general upper-secondary schools were not legally obliged to provide special education. The new law endorsed during the autumn of 2018 will come into force and be implemented through the new curricula during 2019-2021. (see Niemi \& Laaksonen 2019.)

\section{Inequality}

Children and young people from diverse minoritized backgrounds face racism and othering in secondary school, which causes fear and exclusion (e.g. Kurki 2019; Souto 2011; Rastas 2009). Young people from a migrant background are less likely to have an upper-secondary qualification. Over 86 per cent of young people in Finland matriculate from upper secondary school within eight years after completing lower-secondary education, whereas the percentage varies from 50 to 76 among several migrant groups. Family educational background and earlier school success explain a significant proportion of these differences, but not all. Non-Finnish citizens and visibly minoritized groups are the most vulnerable. (Kilpi-Jakonen 2013, 2017.) Pupils with an ethnic-minority background also tend to be guided towards vocational rather than academic tracks (Kurki 2019; Souto 2016). Newly arrived young migrants and unaccompanied minors aged 17 and above, when compulsory education finishes, risk missing out on upper-secondary education (Kivijärvi et al. 2015).

The Roma have historically been excluded from education and systematically subjected to societal assimilation through education (Helakorpi et al. 2018). Despite various measures and practices (Helakorpi et al. 2018), the educational transitions of Roma students remain disjointed and uncertain: general upper-secondary education is a rare choice, and under 10 per cent of them have a tertiary-level degree (Rajala et al. 2011; Rajala \& Blomerus 2015).

Expectations, practices and materials in schools are heteronormative and often exclusive for LGBTIQ+-youth. Explicit acknowledgment of sexual and gender minorities is rare in curriculum documents, and neither teachers nor materials adequately address LGBTIQ+ issues in secondary schools. (Kjaran \& Lehtonen 2018.) According to the results of a survey targeted at LGBTIQ+ youth, 75 per cent hid their sexual orientation or gender identity from teachers, and 50 per cent from their peers in school. About 60 per cent of sexual-minority and trans-youth respondents had experienced bullying, from 4.9 (sexual minorities) to 7.5 (trans) per cent of them experiencing it weekly or daily. A significant proportion of trans youth in particular reported that bullying had resulted in their nonattendance at school. (Alanko 2014.)

Special needs education is considered affirmative action, promoting educational equality in the Finnish school system. Simultaneously, it differentiates pupils and directs them towards different educational tracks (Mietola \& Niemi 2014; Jauhiainen \& Kivirauma 1997). Even though not visible in descriptions of the educational system, there are differentiated post-compulsory programs aimed at disabled students, most of which are based at separate special-education vocational institutes (Hakala et al. 2013). The overall educational level of disabled people is notably lower than that of the whole population (Eurostat 2017; Mahlamäki 2013), and there are marked differences between disability groups in terms of post-compulsory educational opportunities (Kauppila et al. 2018; Ahonen \& Lampinen 2017; Hakala et al. 2013). The disabled people are less likely to matriculate from upper-secondary education and to continue to higher education (Kirjavainen et al. 2016). The majority of them study in vocational upper-secondary institutions, and a small minority in general upper-secondary education (Kirjavainen et al. 2016; Niemi \& Mietola 2017).

With regard to social class, school choices concerning selective and specialized classes and language choices in primary and lower secondary school function as de facto streaming policies and socially segregative mechanisms (Kosunen et al. 2016, Seppänen 2006), which leads to between- and withinschool segregation (Kosunen 2014) as members of the (upper) middle class successfully exercise 
their choice options (Seppänen et al. 2015). Social class and gender also shape peer relations and popularity hierarchies within secondary schools, thus contributing in more subtle ways to experiences of inclusion/exclusion and preferred school trajectories (e.g. Käyhkö 2006; Tolonen 2012; Aaltonen \& Karvonen 2016). The offspring of highly educated parents are known to progress from secondary education more quickly than children of parents with a basic or secondary education (OSF 2019b).

\section{Assistance and resources}

Preparatory teaching and the teaching of Finnish as a second language are targeted forms of support in comprehensive education for pupils with a migrant background. The support structures are less developed in upper secondary schools, however, and vary by municipality and school. (Kivijärvi et al. 2015)

A three-tiered support system provides support for learning in lower-secondary education, and upper secondary vocational schools offer special support. General upper secondary schools do not have established practices, and forms of support vary between schools and municipalities (see Niemi \& Laaksonen, forthcoming).

Preparatory education for vocational training (VALMA), Preparatory training for work and independent living (TELMA) and Preparatory training for general upper-secondary education (LUVA) are examples of curriculum-based short-term programs aimed at the promoting educational transition from lower- to upper-secondary school, or to working life and independent living. The VALMA program is targeted at young people and adults who need the skills to undertake vocational education; the LUVA program promotes the transition to general upper-secondary education among migrant students, and TELMA is aimed at more severely disabled young people who are considered ineligible to apply for vocational education (see Kauppila et al. 2018).

\section{Further reading and online resources}

Alemanji, Aminkeng Atabong (2016), Is there such a thing...? A study of antiracism education in Finland. Helsinki: University of Finland.

Finnish National Agency of Education (2019), Finnish education in a nutshell, https://www.oph.fi/download/171176_finnish_education_in_a_nutshell.pdf [accessed 29 April 2019].

Hahl, K., Niemi, P-M., Johnson Longfor, R. and Dervin, F. (eds)(2015), Diversities and interculturality in textbooks - Finland as an example, Newcastle upon Tyne: Cambridge Scholars.

Kallio, J., Kauppinen, T. and Erola, J. (2016), 'Cumulative socio-economic disadvantage and secondary education in Finland', European Sociological Review, 32(5), 649-661.

Lahelma, E. and Tainio, L (2019), 'The long mission towards gender equality in teacher education: Reflections from a national project in Finland', Nordic Studies in Education (forthcoming).

\section{References}


Aaltonen, S. and Karvonen, S. (2016), 'Floating downstream? Family background, parental support and future expectations of young people from less privileged backgrounds', Sociology 50(4), 714730 .

Ahonen, K. and Lampinen, P. (2017), 'Vammaisten nuorten siirtymävaiheet - onko Suomessa varaa koulutusjärjestelmään, joka ei johda mihinkään?', Nuorisotutkimus, 35(4), 50-54.

Alanko, K. (2014), Mitä kuuluu sateenkaarinuorille Suomessa?, Helsinki: Finnish Youth Research Society.

Eurostat (2017), Disability statistics, Eurostat, http://ec.europa.eu/eurostat/statisticsexplained/index.php/Disability_statistics [accessed 10 October 2017].

From, T. and Sahlström, F. (2017), Shared places, separate spaces: Constructing cultural spaces through two national languages in Finland. Scandinavian Journal of Educational Research, 61(4), 465-478.

Hakala, K., Mietola, R. and Teittinen, A. (2013), 'Valinta ja valikointi ammatillisessa erityisopetuksessa', in Brunila, K., Hakala K., Lahelma, E. and Teittinen, A. (eds), Ammatillinen koulutus ja yhteiskunnalliset eronteot, Helsinki: Gaudeamus, 173-200.

Helakorpi, J., Lappalainen, S. and Mietola, R. (2018), 'Equality in the Making? Roma and Traveller Minority Policies and Basic Education in Three Nordic Countries', Scandinavian Journal of Educational Research (online first) https://doi.org/10.1080/00313831.2018.1485735

Holmberg, L., Kalalahti, M., Varjo, J., Kivirauma, J., Mäkelä, M-L., Saarinen, M., Zacheus, T. and Jahnukainen, M. (2018), 'Educational trajectories of immigrant-origin youths in Finland: A mixed methods analysis', Journal of education and work 31(7-8), 563-578.

Jauhiainen, A. and Kivirauma, J. (1997), 'Disabling school? Professionalisation of special education and student welfare in the Finnish compulsory school', Disability \& Society, 12(4), 623-641.

Kauppila, A., Mietola, R. and Niemi, A-M. (2018), 'Koulutususkon rajoilla: koulutuksen julma lupaus kehitys- ja vaikeavammaisille opiskelijoille', in Silvennoinen, H., Kalalahti, M. and Varjo, J. (eds), Koulutuksen lupaukset ja koulutususko. Kasvatussosiologian vuosikirja II, Jyväskylä: The Finnish Educational Research Association, 209-242.

Kilpi-Jakonen, E. (2014), 'Citizenship and Educational Attainment amongst the Second Generation: An Analysis of Children of Immigrants in Finland', Journal of Ethnic and Migration studies 40(7), 1079-1096.

Kilpi-Jakonen, E. (2017), 'Maahanmuuttajien lasten koulutussiirtymät toisen asteen koulutuksen läpi ja korkeakouluihin', Kasvatus 48(3), 217-231.

Kirjavainen, T., Pulkkinen, J. and Jahnukainen, M. (2016), 'Special education students in transition to further education: A four-year register-based follow-up study in Finland', Learning and Individual Differences 45, 33-42.

Kivijärvi, A., Peltola, M. and Souto, A-M. (2015), 'Maahanmuuttajataustaisten nuorten onnistuneiden koulutussiirtymien tukeminen', in Määttä, M. and Määttä, A. (eds), Parempia ratkaisuja koulutuksen 
ja työn ulkopuolella olevien nuorten tukemiseen, Helsinki: Government analysis, assessment and research activities, 23-26.

Kjaran, J. and Lehtonen, J. (2018), 'Windows of opportunities: Nordic perspectives on sexual diversity in education', International Journal of Inclusive Education 22(10), 1035-1047.

Kosunen, S., Bernelius, V., Seppänen, P., and Porkka, M. (2016b), 'School choice to lower secondary schools and mechanisms of segregation in Urban Finland', Urban Education (online first), https://journals.sagepub.com/doi/full/10.1177/0042085916666933

Kosunen, S. (2014), 'Reputation and parental logics of action in local school choice space in Finland', Journal of Education Policy, 29(4), 443-466.

Kurki, T. (2019), Immigrant-ness as (mis)fortune? Immigrantisation through integration policies and practices in education, Helsinki: University of Helsinki.

Käyhkö, M. (2006), Siivoojaksi oppimassa. Työläistyttöjen kasvatus ja moraalinen säätely, Joensuu: University of Joensuu.

Luopa, P., Kanste, O., and Klemetti, R. (2017), Toisella asteella opiskelevien sateenkaarinuorten hyvinvointi 2017. Kouluterveyskyselyn tuloksia, Helsinki: National Institute for Health and Welfare.

Mahlamäki, Pirkko (2013), 'Vammaisten ihmisoikeudet eivät toteudu', Hyvinvointikatsaus 3/2013, Helsinki: Statistics Finland.

Mietola, R. and Niemi, A-M. (2014), 'Erityisopetus ja koulutuksellisen inkluusion toteutuminen', in Pulkkinen, S. and Roihuvuori, J. (eds), Erkanevat koulutuspolut: Koulutuksen tasa-arvon tila 2010luvulla, Helsinki: Suomen ylioppilaskuntien liitto, 66-83.

Niemi, A-M. (2015), Erityisiä koulutuspolkuja? Tutkimus erityisopetuksen käytännöistä peruskoulun jälkeen, Helsinki: University of Helsinki.

Niemi, A.-M. and Laaksonen, L. M. (2019), 'Discourses on educational support in the context of general upper secondary education', Disability \& Society.

https://doi.org/10.1080/09687599.2019.1634523

Nylund, M., Rosvall, P-Å., Eiriksdottir, E., Holm, A-S., Isopahkala-Bouret, U., Niemi, A-M. and Ragnarsdottir, G. (2018), 'The academic-vocational divide in three Nordic countries: implications for social class and gender', Education Inquiry 9(1), 97-121.

Official Statistics Finland (OSF) (2019a), Population structure, Helsinki: Statistics Finland, https://www.stat.fi/til/vaerak/tau_en.html [accessed 2 April 2019].

Official Statistics Finland (OSF) (2019b), 'Parents' educational background connected to passing upper secondary level education', Progress of studies, Helsinki: Statistics Finland, http://www.stat.fi/til/opku/2019/opku_2019_2019-03-14_tie_001_en.html [accessed 16 April 2019].

Official Statistics of Finland (OSF): Special education [e-publication]. ISSN=1799-1617. Helsinki: Statistics Finland [referred: 12.11.2019]. Access method: http://www.stat.fi/til/erop/index_en.html 
Rajala, S. and Blomerus, S. (2015), Katsaus aikuisten romanien koulutustaustoihin, Helsinki: Finnish National Agency for Education.

Rajala, S., Salonen, M., Blomerus, S. and Nissilä, L. (2011), Romanioppilaiden perusopetuksen tilannekatsaus 2010-2011 ja toimenpide-ehdotukset, Helsinki: Finnish National Agency for Education.

Rastas, A. (2009), 'Racism in the everyday life of Finnish children with transnational roots', Barn 27 (1), 29-43.

Seppänen, P. (2006), Kouluvalintapolitiikka perusopetuksessa: suomalaiskaupunkien koulumarkkinat kansainvälisessä valossa, Turku: Suomen kasvatustieteellinen seura.

Seppänen, P., Kalalahti, M., Rinne, R., and Simola, H. (2015), Lohkoutuva peruskoulu - Perheiden kouluvalinnat, yhteiskuntaluokat ja koulutuspolitiikka, Turku: Suomen kasvatustieteellinen seura.

Souto, A.-M. (2016), 'Etnistyvät toisen asteen koulutusvalinnat', Nuorisotutkimus, 34(4), 47-59.

Souto, A-M (2011), Arkipäivän rasismi. Etnografinen tutkimus suomalais- ja

maahanmuuttajanuorten ryhmäsuhteista, Helsinki: Finnish Youth Research Society.

Taavetti, R. (2015), "Olis siistiä, jos ei tarttis määritellä..." Kuriton ja tavallinen sateenkaarinuoruus, Helsinki: Finnish Youth Research Society.

Tainio, L. and Kallioniemi, A. (eds) (2019), Koulujen monet kielet ja uskonnot - Selvitys vähemmistöäidinkielten ja-uskontojen sekä suomi ja ruotsi toisena kielenä-opetuksen tilanteesta eri koulutusasteilla, Helsinki: Government analysis, assessment and research activities.

Tolonen, T. (2012), 'Classed and gendered meanings of marginalisation in young people's transitions', in Tolonen T., Palmu, T., Lappalainen, S. and Kurki, T. (eds) Cultural Practices and transitions in education, London: Tufnell Press, 126-137.

Vipunen (2019), Yliopisto-opiskelijoiden aikaisempi koulutus, Vipunen - Opetushallinnon tilastopalvelu, https://vipunen.fi/fi-fi/yliopisto/Sivut/Aiempi-ja-my\%C3\%B6hempi-koulutus.aspx [accessed 24 April 2019].

Zilliacus, H. (2013), 'The Inclusion of Minority Religious Education in the Finnish Comprehensive School: A Teacher and Teacher Coordinator Perspective', Nordidactica: Journal of Humanities and Social Science Education, 2013(2), 93-114.

Zilliacus, H. (2014), Supporting student's identities and inclusion in minority religious and secular ethics education: A study on plurality in the Finnish comprehensive school. Helsinki: University of Helsinki.

\section{Approval Log}

\section{Bloomsbury Check}

- Word count is $1,000-1,500$ ( $10 \%$ above \& below is acceptable) $\otimes$ If not, specify current word count 
- Image files and copyright permissions have been supplied (where appropriate) $\bigotimes$

- Section, Article topic and Country listed at the top of article are as per contract. $\bigotimes$

- Keywords (5-10) are listed. $\otimes$

- Glossary terms are listed and highlighted throughout article. $\bigotimes$

- Further Reading and Online Resources section is present (5-10 suggestions). $\square$

- References section is present. $\bigotimes$

\section{Regional Editor Check}

- The text reflects and includes all of the subheadings from the Article Outline $\square$

- The text is aligned with relevant ISCED standards or age range $\square$

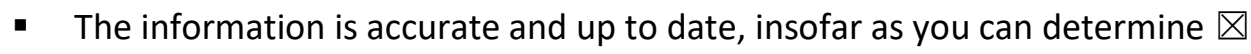

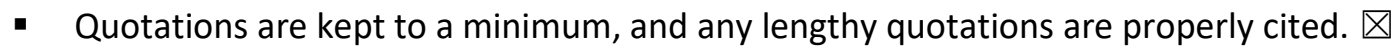

- Routine moderate copyediting required $\otimes$

- Heavy copyediting required

If heavy copyediting required, note reasons and details:

- Article approved by Regional Editor $\bigotimes$

If article is not approved, note reasons below:

\section{Editor in Chief}

- Article approved by relevant Editor in Chief

If article is not approved, note reasons below: 